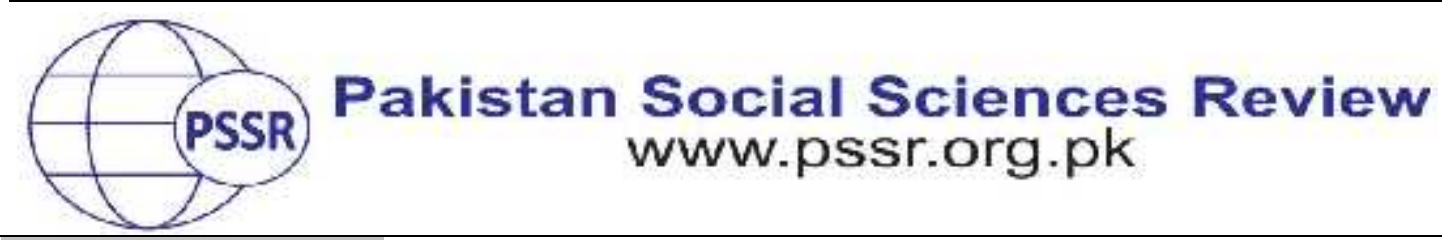

\title{
RESEARCH PAPER \\ Analysis of Gap between Expected and Achieved Levels of Skills related Learning Outcomes of Graduates
}

\author{
Farhana $\mathrm{Akmal}^{*_{1}}$ Professor Ashfaque Ahmad SHAH ${ }^{2}$ \\ Professor Dr. Muhammad Sarwar ${ }^{3}$
}

1. PhD Scholar, Department of Education, University of Sargodha, Punjab, Pakistan

2. Dean Faculty of Education, Humanities and Social Sciences, Chairperson Department of Educational Development University of BaltistanSkardu, Pakistan

3. Director, QEC, University of Sargodha, Punjab, Pakistan

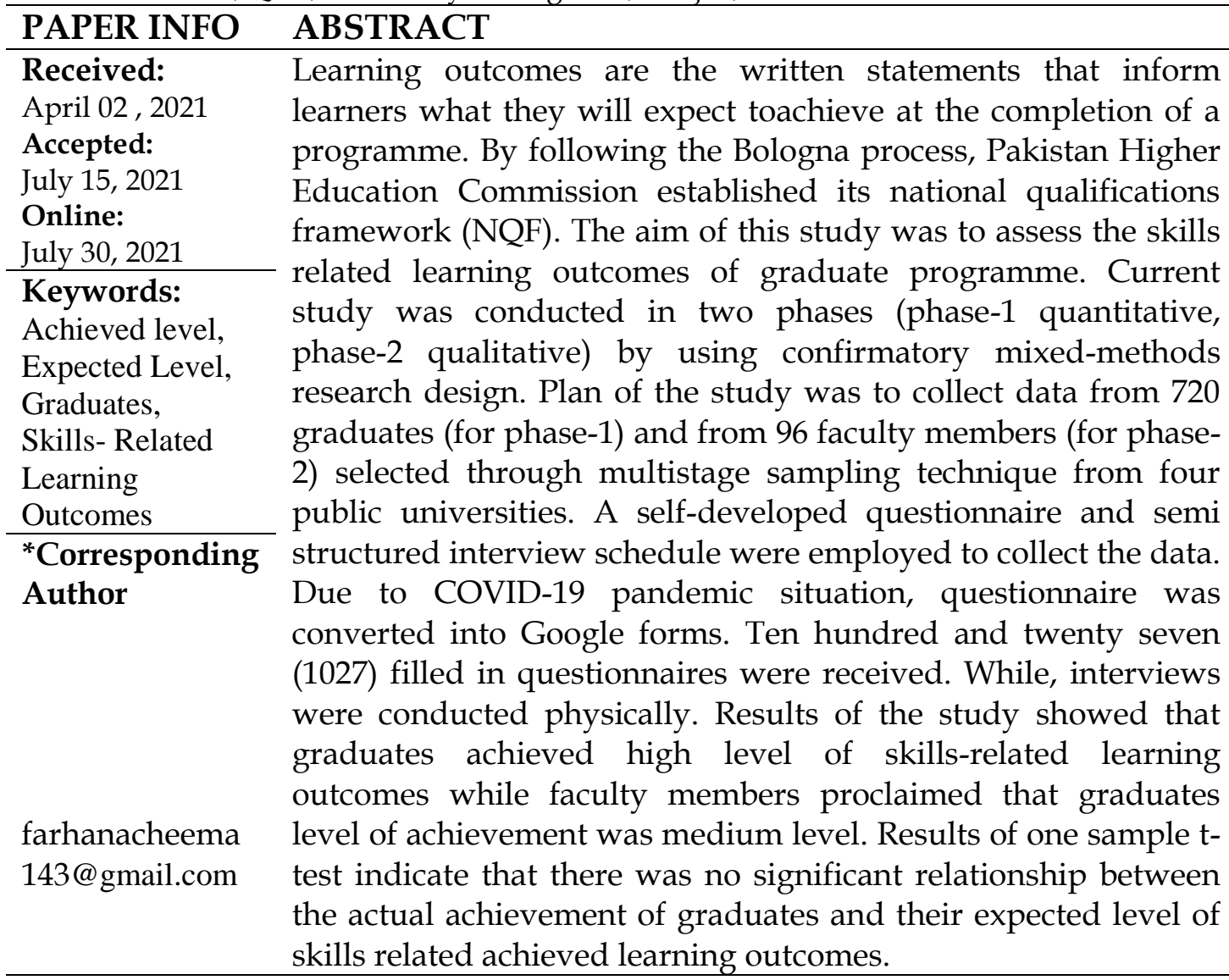

\section{Introduction}

Learning outcomes give a strong idea to a learner that what he could achieve by joining aprogramme and use to know whether the course is designed and conducted perfectly (Mahajan\& Singh, 2017). 
In the educational literature, the term learning outcomes has been discussed during last two decades (Tam, 2014).

Furthermore, there has been a disagreement on the practise and misuse of learning outcomes. Some practitioners preferred for the addition of learning outcomes in the educational system. On the other hand, some of severely criticised them(Hussey \& Smith, 2003).

Regarding the critiques point of view,learning outcomes are being exploited as a tool for educational impoverishment. Most of the time, it was only a formality on the part of the organisation. They played an important role in actual evolution of learners. They have acted as roadblocks in the real assessment of students.Same like, some other researchers advocate that learning outcomes play a comprehensive role in curriculum design, effective learning assessment and maintaining quality assurance of educational system. They also said that learning outcomes supported for the quality assurance of educational process Lawless et al., (2007).

Learning outcomes classified in numerous ways. For instance, James and Brown (2005) learning outcomes classified into seven categories achievement, apprehending, intellectual and innovative, by means of higher-order learning, dispositions and membership. Although, European Qualifications Framework (EQF) and National Qualifications Framework (NQF) classified the learning outcomes into three categories knowledge, skills and competence(Kettunen et al., 2013).

Skills related learning outcomes mean an ability for completing a task, problem solving, applying knowledge.Adam (2006) said that skills related learning outcomes mean ability to apply knowledge.

Learning outcomes are considering very important for improving the quality and effectiveness of educational programmes. Numerous scholars have shifted their focus from their study to learning outcomes analysis.

For instance, Aryanti and Adhariani (2020) investigated perception of accounting students and expectation of employers towards the knowledge and skills. Findings of the study showed that,there is a gap in expectationsof students and employers to skills not knowledge.

Abbasi and Bibi (2018) conducted a study to identify skills-related gaps in achieved learning outcomes.

A study by Abbasi and Bibi (2018) to identify the gap between skills expected by managers and skills possessed by business graduates employed by banking industry. Findings of the study was reveled that, significant skill gaps were found. 
Alshare and Sewailem (2018) discovered a significant gap between business graduates' perceived and required level of skills.Oczkowska and Wisniewska (2017) found a significant gap in competence achievement. Kamphorst et al. (2013) investigated the relationship between perceived competence and earned credits among Dutch students. Findings of the study was revealed a weaker relationship.

In a few words, the majority of studies on learning outcomes were conducted in Western countries.In the context of Pakistan, Huma and Mahboob (2020) conducted research in Pakistan to compare the learning outcomes mentioned in the Pakistan Qualifications Framework (2005) and the National Qualifications Framework (NQF), 2015 with graduate programme outlines.

Shah et al., (2020) reported a study, which simply compared the acquired learning outcomes of BEd and MA education graduates. They did not take into account the components of NQF. National qualification framework define the components of learning outcomes as (knowledge, skills and competence).

Moreover, all of these above mentioned prior studies have been conducted at international level. The majority of the study carried out to identify the desired level and acquired level of learning outcomes. Result of the studies were found a significant gap between the perceived and expected level of learning outcomes. Meanwhile, this fact provoked researchers to investigate whether or not Pakistani graduates face the same achievement gap in learning outcomes.In the context of Pakistan, studies have been conducted purely on the basis of compared learning outcomes. In previous studies,comparison of studies were carried out in the absence of a national qualification framework (NQF). Following the Bologna process, Pakistan developed its NQF, as did many other countries around the world. Learning outcomes are explicitly described all levels of qualifications in National qualifications framework (NQF). In the National Qualifications Framework, graduate level is also referred to (NQF). It follows that no study has been conducted to follow the NQF learning outcomes.

This situation necessitates a thorough investigation for a rigorous study to analyses skills related achieved learning outcomes and gaps between expected and achievedlevel of learning outcomes with reference to national qualification framework (NQF).

Therefore, current study was carried out to analyse the gap between the desired and acquired skills related learning outcomes of graduates with reference national qualifications framework (NQF) of Pakistan.

\section{Material and Methods}

\section{Research Design of the Study}

A mixed methods research design was used in this analysis. When conducting mixed methods research, the researcher collects both quantitative and 
qualitative data in order to gain a deeper understanding of the research issue. In other words, one form of research data (quantitative or qualitative) appears inadequate to adequately answer a research question or solve the research issue, or additional data is needed to expand, clarify, or elaborate on the first data base (quantitative or qualitative) (Creswell\& Plano, 2012).

Various mixed methods designs have been proposed by a number of researchers. Creswell \& Plano (2014) also identified six major styles of mixed methods research designs.

The convergent parallel design collects both quantitative and qualitative data at the same time, and is one of six forms of mixed methods design. Two phases of data collection are included in the explanatory sequential design. Quantitative data is collected in phase one, and qualitative data is collected in phase two to justify the quantitative findings (Creswell \& Plano, 2011).

Confirmatory mixed methods design is another name for this type of study (Tashakkori and Teddlie 1998). The exploratory sequential design purposes to investigate a phenomenon by collecting qualitative data first, then quantitative data to explain the relationships found in the qualitative data.

Quantitative and qualitative data are obtained simultaneously, according to the embedded design. However, one type of data may be used to endorse another type of data; supportive data may be quantitative or qualitative. The transformative design explains the study's intent and discusses ideological and value-based concerns such as prejudice and ethical disability (Greene, 2007).

The multiphase layout illustrates how a group of researchers examines an issue through a sequence of phases. Convergent, explanatory, exploratory, and embedded design are used (Creswell et al., 2011). In this study, the researchers did not collect data simultaneously, did not investigate the phenomenon, did not explain the study's intent, and did not use number of phases to analyse the problem by a group of researchers. The confirmatory mix methods design is used to validate quantitative findings by qualitative analysis. The aim of this study was to quantitatively evaluate skills levels of graduates before validating them through qualitative data analysis. As a result, the confirmatory mix methods design was used to carry out this study.

\section{Population of the Study}

According to Scheaffer et al., (2006), a population is described as 'a set of components from which we want to draw conclusions'. Higher Education Commission started that, Pakistan has 214 accredited universities (public $=131$, private $=83$ ). In Punjab, there are 65 universities that are accredited by the Higher Education Commission $(\mathrm{HEC})$ (public $=39$, private $=26$ ). The population of the study consisted of all graduate students from all public sector universities in Punjab 
(http: //hec.gov.pk/English/universities/pages/recognised. as per retrieved on 0801-2020).

\section{Delimitation of the Study}

Current research was delimited to BS program of six departments at four public sector universities in province Punjab Pakistan.

\section{Phases of the Study}

Current study was carried out in two phases. Phase-1was quantitative while phase-2 was qualitative.

\section{Phase-1 of the Study: the Quantitative Phase}

During phase-1

Skills related achieved learning outcomes of graduates were analysed quantitatively.

\section{Sampling and Sample}

The sample of the study was collected by using a multi-stage sampling technique. At first stage, four public universities were chosen, along with three disciplines (natural sciences, social sciences, and languages). At the second stage, six departments were chosen from each selected university in Punjab Province, two from each discipline: Chemistry and Physics from natural sciences, Education and History from social sciences, and Urdu and English from languages. At the third stage, thirty (30) graduate were chosen conveniently from each department (180 from each university).

As a result, the study sample consisted of 816 graduate from all of the chosen universities. These three disciplines, natural sciences, social sciences, and languages, were not offered by any private universities. So, the private universities were left out from this study. This research was limited to three disciplines and six departments of public sector universities from Pakistan Punjab province.

\section{Data Collection for phase-1}

The coronavirus (COVID-19) is causing a worldwide epidemic. This disease has a large global impact. The entire world is battling with this disease. Due to the severe corona situation in Pakistan, researcher was unable to collect data physically. All educational institutes in the country were closed. Therefore,researcher was unable to physically obtain data from the chosen universities. After consultation with the supervisor, it was decided that the data would be collected electronically. Therefore, questionnaire was converted into Google form. After that, the researcher seek permission to the chosen universities from the head of the departments (HODs). The heads of the chosen departments were given contact numbers of class 
representatives (CRs'). The Google form link was shared with class WhatsApp groups, with the coordination of CRs. For the completion of this study, 720 graduates were required. A total of 1027 responses were received from the selected departments of each of the sampled universities.

\section{Analysis of the Data Phase-1}

Data were analysed with the help of SPSS version 21. Mean and standard deviation were calculated to analyse the skills related achieved learning outcomes of graduate programmes. One sample t-test was also employed to find the gaps at skills level learning outcomes.

Table 1

Graduates Achieved Level Skills related Learning Outcomes

\begin{tabular}{|c|c|c|c|c|c|c|c|c|c|}
\hline $\begin{array}{l}\text { Statements } \\
\text { Graduate degree gives } \\
\text { skills of }\end{array}$ & SA & A & $\mathrm{SA}+\mathrm{A}$ & UND & DA & SDA & $\begin{array}{l}\text { SDA } \\
+ \text { DA }\end{array}$ & $\underset{\mathbf{n}}{\mathrm{Mea}}$ & Level \\
\hline $\begin{array}{l}\text { 1.use of theoretical } \\
\text { knowledge in the field }\end{array}$ & 18.2 & 63.1 & 81.3 & 7.4 & 6.4 & 4.9 & 11.3 & 3.83 & High \\
\hline $\begin{array}{l}\text { 2. use of computer in the } \\
\text { field }\end{array}$ & 26.7 & 53.7 & 80.4 & 7.8 & 9.3 & 2.4 & 11.7 & 3.93 & High \\
\hline $\begin{array}{l}\text { 3. use of practical } \\
\text { knowledge in the field }\end{array}$ & 29.7 & 51.4 & 81.1 & 7.0 & 8.3 & 3.6 & 11.9 & 3.95 & High \\
\hline $\begin{array}{l}\text { 4. use of new knowledge } \\
\text { within the field }\end{array}$ & 25.2 & 55.2 & 80.4 & 9.1 & 7.8 & 2.7 & 10.5 & 3.92 & High \\
\hline $\begin{array}{l}\text { 5. develop innovative } \\
\text { knowledge within the field }\end{array}$ & 20.0 & 57.4 & 77.4 & 11.3 & 8.1 & 3.3 & 11.4 & 3.83 & High \\
\hline $\begin{array}{l}\text { 6. interpret the data within } \\
\text { the field }\end{array}$ & 17.4 & 57.2 & 74.6 & 13.0 & 8.7 & 3.7 & 12.4 & 3.76 & High \\
\hline $\begin{array}{l}\text { 7. develop an innovative } \\
\text { method within the field }\end{array}$ & 17.0 & 58.7 & 75.7 & 11.9 & 8.8 & 3.6 & 12.4 & 3.77 & High \\
\hline $\begin{array}{l}\text { 8. develop solution of the } \\
\text { complex problems within } \\
\text { the field }\end{array}$ & 18.4 & 56.5 & 74.9 & 13.7 & 8.2 & 3.2 & 11.4 & 3.79 & High \\
\hline $\begin{array}{l}\text { 9. evaluate the data in the } \\
\text { research field }\end{array}$ & 20.0 & 57.7 & 77.7 & 11.6 & 8.0 & 2.7 & 10.7 & 3.84 & High \\
\hline $\begin{array}{l}\text { 10. solve complex problem } \\
\text { through application of } \\
\text { knowledge in the field }\end{array}$ & 20.4 & 56.8 & 77.2 & 11.6 & 7.8 & 3.4 & 11.2 & 3.83 & High \\
\hline $\begin{array}{l}\text { 11. analyze the difficult } \\
\text { situation }\end{array}$ & 20.5 & 61.3 & 81.8 & 9.0 & 6.5 & 2.6 & 9.1 & 3.91 & High \\
\hline $\begin{array}{l}\text { 12. contribute in the } \\
\text { research activities }\end{array}$ & 21.4 & 57.3 & 78.7 & 10.3 & 7.8 & 3.2 & 11.0 & 3.86 & High \\
\hline $\begin{array}{l}\text { 13. develop an innovative } \\
\text { report writing }\end{array}$ & 19.5 & 54.3 & 73.8 & 14.3 & 8.1 & 3.8 & 11.9 & 3.78 & High \\
\hline Overall percentage of skills & 21.1 & 57 & 78.0 & 10.6 & 8 & 3.3 & 11.3 & 3.84 & High \\
\hline
\end{tabular}

Table 1 shows the skills related achieved learning outcomes of graduates. The data in the table indicate that the graduates achieved high level of skills' to use of theoretical knowledge in the field, 'use of practical knowledge in the field,'use of 
computer in the field,'use of new knowledge within the field,'develop innovative knowledge within the field,'develop solution of the complex problems within the field,'evaluate the data in the research field,'solve complex problem through application of knowledge in the field,'analyze the difficult situation,'contribute in the research activities and 'develop an innovative report writing,

However, the data was revealed that graduate degree gave the high level skills to the graduate students.

Table 2

Gap between Expected and Achieved Level of Skills

\begin{tabular}{|c|c|c|c|c|c|c|}
\hline Learning Outcomes & Level & $\mathbf{M}$ & Gap & SD & $\mathbf{t}$ & $\mathbf{P}$ \\
\hline \multirow{2}{*}{1 use of theoretical knowledge in the field } & Achieved & 3.83 & \multirow{2}{*}{-1.17} & \multirow{2}{*}{0.962} & \multirow{2}{*}{-38.88} & \multirow{2}{*}{.000} \\
\hline & Expected & 5.00 & & & & \\
\hline \multirow{2}{*}{ 2. use of computer in the field } & Achieved & 3.93 & \multirow{2}{*}{-1.07} & \multirow{2}{*}{0.966} & \multirow{2}{*}{-35.53} & \multirow{2}{*}{.000} \\
\hline & Expected & 5.00 & & & & \\
\hline \multirow{2}{*}{ 3. use of practical knowledge in the field } & Achieved & 3.95 & \multirow{2}{*}{-1.05} & \multirow{2}{*}{1.011} & \multirow{2}{*}{-33.20} & \multirow{2}{*}{.000} \\
\hline & Expected & 5.00 & & & & \\
\hline \multirow{2}{*}{ 4. use of new knowledge within the field } & Achieved & 3.92 & \multirow{2}{*}{-1.08} & \multirow{2}{*}{0.946} & \multirow{2}{*}{-36.45} & \multirow{2}{*}{.000} \\
\hline & Expected & 5.00 & & & & \\
\hline \multirow{2}{*}{$\begin{array}{l}\text { 5. develop innovative knowledge within } \\
\text { the field }\end{array}$} & Achieved & 3.83 & \multirow{2}{*}{-1.17} & \multirow{2}{*}{0.951} & \multirow{2}{*}{-39.57} & \multirow{2}{*}{.000} \\
\hline & Expected & 5.00 & & & & \\
\hline \multirow{2}{*}{ 6. interpret the data within the field } & Achieved & 3.76 & \multirow{2}{*}{-1.24} & \multirow{2}{*}{0.963} & \multirow{2}{*}{-41.28} & \multirow{2}{*}{.000} \\
\hline & Expected & 5.00 & & & & \\
\hline \multirow{2}{*}{$\begin{array}{l}\text { 7. develop an innovative method within } \\
\text { the field }\end{array}$} & Achieved & 3.77 & \multirow{2}{*}{-1.23} & 0.055 & 1125 & 000 \\
\hline & Expected & 5.00 & & 0.955 & -41.35 & .000 \\
\hline 8. develop solution of the complex & Achieved & 3.79 & 121 & 0015 & & 000 \\
\hline problems within the field & Expected & 5.00 & -1.21 & 0.943 & -41.14 & (0) \\
\hline 9 evaluate the data in the research field & Achieved & 3.84 & -116 & 0925 & -4010 & 000 \\
\hline 9. evaluate the data in the researcn nela & Expected & 5.00 & -1.10 & & & (000 \\
\hline 10. solve complex problem through & Achieved & 3.83 & 17 & 0054 & 3027 & 000 \\
\hline application of knowledge in the field & Expected & 5.00 & $-1.1 /$ & 0.954 & -39.27 & (0) \\
\hline 11 analyce the difficult citurtion & Achieved & 3.91 & 109 & 0986 & 3956 & 000 \\
\hline 11. anaryse the ammicuit situation & Expected & 5.00 & -1.09 & 0.900 & -39.00 & (000 \\
\hline 12 contribute in the research astivities & Achieved & 3.86 & -114 & 0948 & -3857 & 000 \\
\hline & Expected & 5.00 & & & & \\
\hline 13 develon an innovative renort writino & Achieved & 3.78 & -122 & 0.977 & -4017 & 000 \\
\hline & Expected & 5.00 & & & & \\
\hline
\end{tabular}

Table 2 shows that one-sample t-test was applied to know the gap between expected and achieved level of skills related learning outcomes of graduates. Data in the table indicate that there exists a significant gap between achieved and expected level of skills related learning outcomes obtain by the graduates. It is evident that they achieved high level of skills related learning outcomes of graduates is lesser than the expected skills level in all the 13 indicators.

Table 3

Correlation between Perceived and Actual Achievement of Learning Outcomes

\begin{tabular}{ccc}
\hline Variable & & Achievement \\
\hline \multirow{2}{*}{ Skills } & $\mathrm{R}$ & 0.05 \\
\cline { 2 - 3 } & $\mathrm{p}$-value & 0.126 \\
\hline & &
\end{tabular}


The table 3 describes that the Pearson correlation was calculated to find the relationship between the perceived achievement level of skills-related learning outcomes and the actual achievement (CGPA) of graduates. The results indicate that there was no significant relationship between the actual achievement of graduates and their perceived level of skills-related acquired learning outcomes.

\section{Skills related Achieved Learning Outcomes}

It was found that skills related achieved high level of skills related learning outcomes. In the same manner, graduate achieved high level skills in its indicators including 'to use of theoretical knowledge in the field, 'use of practical knowledge in the field,'use of computer in the field,'use of new knowledge within the field,'develop innovative knowledge within the field,'develop solution of the complex problems within the field,'evaluate the data in the research field,'solve complex problem through application of knowledge in the field,'analyze the difficult situation,'contribute in the research activities and 'develop an innovative report writing,

\section{Achievement Gap of Skills related Learning Outcomes}

It was found that the achieved level of skills related learning outcomes of graduates is lesser than that of their expected level.

\section{Relationship between reported Learning Outcomes and Actual Achieved Learning Outcomes (CGPA)}

The finding of the quantitative data revealed that there is no significant relationship between expected level of learning outcomes and actual achieved learning outcomes (CGPA) (table 3).

The faculty interviews also revealed that there is no relationship exit significantly at the perceived level of their learning outcomes achievement and what they real achieved (CGPA).

Faculty members included more about that this could be notorious

During their interview, also confirmed that commonly there is no relationship between what graduates perceive about their achievement level of learning outcomes and what they actually attain (CGPA). According to faculty members added that this could be related to the well-known flaw of self-assessment, in which assessors frequently overrate themselves.

\section{Phase-2 of the Study: the Qualitative Phase}

For the confirmation and explanation of the findings of phase- 1 of the study university faculty teachers were interviewed. 


\section{Sample of the Study for Phase-2}

Sample of the study for phase-2 comprised 96 faculty members of the selected public universities of the Punjab. The sample included four faculty members from each selected department (6 departments from each university) 24 faculty members from each university were selected conveniently.

\section{Qualitative Data Collection}

On the basis of findings of quantitative data a semi-structured interview schedule was developed for the confirmation of quantitative findings. It was consisted of six questions and validated through expert opinion.

\section{Analysis of Qualitative Data: Phase-2}

The qualitative data study based on interviews with faculty members is presented in the following section to validate the quantitative data findings (phase$1)$.

The main theme of this study was the learning outcomes of a graduate programme. Which were divided into three subthemes: knowledge, skills, and competence.A questionnaire was used to collect the precipitation from graduates in order to determine their perceived level of learning outcomes.

Graduates stated that their graduate degree provided them with a high level of skills related to learning outcomes. Results of a one-sample t-test showed that there was gap between their expected and achieved levels of skills related learning outcomes. The Pearson correlation results also revealed that there was no significant relationship between graduates' expected achievement and their actual level of achievement (CGPA) of learning outcomes. University faculty members were interviewed to collect their opinions on the extent of achievement of learning outcomes of graduates in order to validate the results of quantitative data.

Maximum faculty members disagreed with the claim that graduates achieved high level of skills related learning outcomes. Rather, they declared that graduates had a medium level of achievement in terms of skills relatedlearning outcomes.

Furthermore, faculty members were also asked to identify the underlying reasons of graduates' not attaining high level of skills related learning outcomes, and recommend suitable measures to bridge the skillslevel achievement gaps.

The given table shows the graduates and faculty member's responses about skills achievement level of learning outcomes, underlying reasons of skills achievement gaps of learning outcomes, and also recommendation of faculty members to bridge these gaps.

\section{Table 4}

\section{Achievement Gap of Skills, its Reasons and the Suggested Measures}




\begin{tabular}{|c|c|c|c|c|c|}
\hline Sub-theme & $\begin{array}{l}\text { Graduates } \\
\text { response }\end{array}$ & $\begin{array}{l}\text { Faculty } \\
\text { members } \\
\text { response }\end{array}$ & $\begin{array}{l}\text { Underlining } \\
\text { reasons by faculty } \\
\text { members }\end{array}$ & $\begin{array}{l}\text { Suggestions by } \\
\text { teachers to achieve } \\
\text { maximum level of } \\
\text { learning outcomes }\end{array}$ & $f$ \\
\hline \multirow{8}{*}{$\begin{array}{l}\text { Achieved } \\
\text { level of } \\
\text { Skills }\end{array}$} & \multirow{8}{*}{$\begin{array}{l}\text { Graduates } \\
\text { claim that } \\
\text { the } \\
\text { graduate } \\
\text { degree } \\
\text { gave them } \\
\text { a high } \\
\text { level of } \\
\text { skills }\end{array}$} & \multirow{8}{*}{$\begin{array}{l}\text { Teachers } \\
\text { claim that } \\
\text { graduate } \\
\text { degree } \\
\text { imparted the } \\
\text { Medium } \\
\text { level of skills }\end{array}$} & $\begin{array}{l}\text { Graduates could } \\
\text { not achieve high } \\
\text { level of skills due } \\
\text { to: } \\
\text { Inadequate lab } \\
\text { equipment }\end{array}$ & $\begin{array}{l}\text { It is prerequisite to } \\
\text { provide } \\
\text { appropriate and } \\
\text { well-established } \\
\text { lab equipment to } \\
\text { develop relevant } \\
\text { skills in students. }\end{array}$ & $(\mathrm{N}=85,88 \%)$ \\
\hline & & & $\begin{array}{l}\text { Unavailability of } \\
\text { expensive } \\
\text { chemicals }\end{array}$ & $\begin{array}{l}\text { The government } \\
\text { must provide } \\
\text { funds to bring } \\
\text { expensive } \\
\text { chemicals and } \\
\text { concentrate on } \\
\text { research-based } \\
\text { education, } \\
\text { particularly in the } \\
\text { sciences. }\end{array}$ & $(\mathrm{N}=85,88 \%)$ \\
\hline & & & $\begin{array}{l}\text { Mismatch between } \\
\text { the university } \\
\text { curricula and } \\
\text { market demands }\end{array}$ & $\begin{array}{l}\text { University } \\
\text { curricula should be } \\
\text { revised according } \\
\text { to the market } \\
\text { demand. }\end{array}$ & $(\mathrm{N}=87,90 \%)$ \\
\hline & & & $\begin{array}{l}\text { Little involvement } \\
\text { of research } \\
\text { projects }\end{array}$ & $\begin{array}{l}\text { Assign a small } \\
\text { research project to } \\
\text { students in order } \\
\text { to improve their } \\
\text { research skills. }\end{array}$ & $(\mathrm{N}=80,83 \%)$ \\
\hline & & & $\begin{array}{l}\text { Much focus on } \\
\text { theoretical rather } \\
\text { than practical } \\
\text { work }\end{array}$ & $\begin{array}{l}\text { The proportion of } \\
\text { practical work } \\
\text { should be } \\
\text { increased in the } \\
\text { curriculum so that } \\
\text { students may } \\
\text { enhance their skills } \\
\text { through } \\
\text { involvement in } \\
\text { practical work. }\end{array}$ & $(\mathrm{N}=82,85 \%)$ \\
\hline & & & $\begin{array}{l}\text { Weaker writing } \\
\text { skills }\end{array}$ & $\begin{array}{l}\text { Needs to develop } \\
\text { and promote basic } \\
\text { writing skills at } \\
\text { earlier stage i.e., at } \\
\text { elementary level. }\end{array}$ & $(\mathrm{N}=80,83 \%)$ \\
\hline & & & $\begin{array}{l}\text { No proper training } \\
\text { workshops } \text { on } \\
\text { developing basic } \\
\text { skills }\end{array}$ & $\begin{array}{l}\text { Training } \\
\text { workshops should } \\
\text { be organized to } \\
\text { improve basic } \\
\text { skills. }\end{array}$ & $(\mathrm{N}=85,88 \%)$ \\
\hline & & & $\begin{array}{l}\text { Limited internship } \\
\text { opportunities }\end{array}$ & $\begin{array}{l}\text { The scope of } \\
\text { internship } \\
\text { programme should } \\
\text { be extended to all }\end{array}$ & $(\mathrm{N}=83,86 \%)$ \\
\hline
\end{tabular}




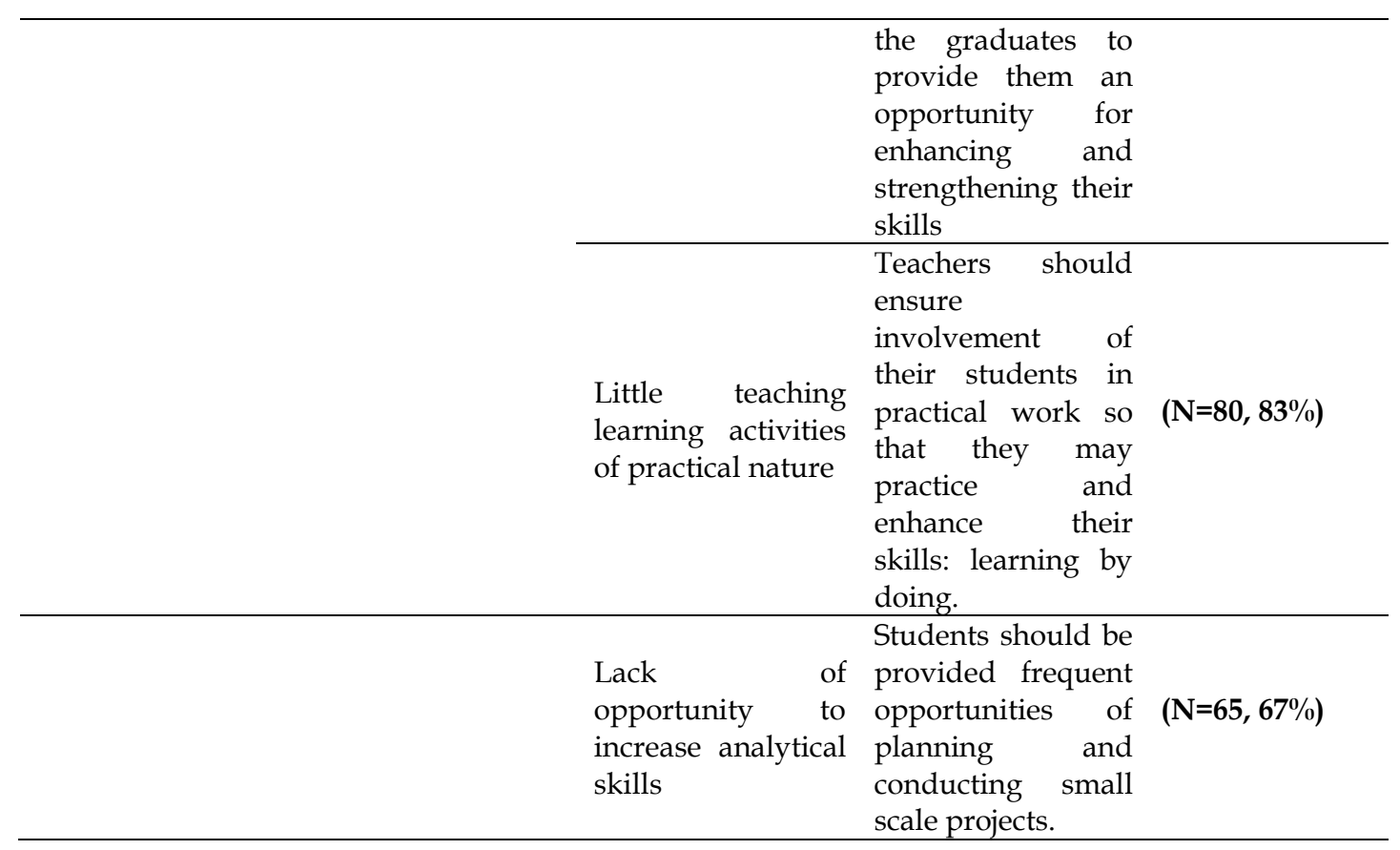

The table 4 depicts the sub themes of faculty members' perceptions of graduates' skills related achieved levellearning outcomes, the responses of faculty members, reasons of contradiction between perception of graduates and faculty members and suggestions given by faculty members to achieve high level skills related to learning outcomes. According to the statistics in the table, graduates reported that their graduate degree provided them with a high level of skills, however university faculty members disagree, claiming that their graduate degree provided them with a Medium level of abilities for a variety of reasons. The faculty members authenticated their standpoint by highlighting the reasons like the responses of faculty members, 'reasons of contradiction between perception of graduates and faculty members and suggestions given by faculty members to achieve high level of skills related earning outcomes. 'inadequate lab equipment' unavailability of expensive chemicals"mismatch between the university curricula and market demands"little involvement of research projects"much focus on theoretical rather than practical work"weaker writing skills"no proper training workshops on developing basic skills "limited internship opportunities ' 'little teaching learning activities of practical nature "lack of opportunity to increase analytical skills'.

Moreover the faculty members also suggested measures to achieve high level of skills related to learning outcomes for example 'it is prerequisite to provide appropriate and well-established lab equipment to develop relevant skills in students "the government must provide funds to bring expensive chemicals and concentrate on research-based education" particularly in the sciences" university curricula should be revised according to the market demand "assign a small research project to students in order to improve their research skills" the proportion of practical work should be increased in the curriculum so that students may 
enhance their skills through involvement in practical work"needs to develop and promote basic writing skills at earlier stage i.e., at elementary level"training workshops should be organized to improve basic skills"the scope of internship programme should be extended to all the graduates to provide them an opportunity for enhancing and strengthening their skills" teachers should ensure involvement of their students in practical work so that they may practice and enhance their skills: learning by doing, 'students should be provided frequent opportunities of planning and conducting small scale projects'.

\section{Findings of Qualitative Data: Phase-2}

\section{Skills related Achieved Learning Outcomes: Faculty Members' Perspective}

Faculty members did not support the claim of graduates regarding high level of skills related achieved learning outcomes at the accomplishments of their graduate degree due to some underlying reasons. These reasons include'the responses of faculty members, 'reasons of contradiction between perception of graduates and faculty members and suggestions given by faculty members to achieve high level of skills related earning outcomes. 'inadequate lab equipment' unavailability of expensive chemicals"mismatch between the university curricula and market demands"little involvement of research projects"much focus on theoretical rather than practical work"weaker writing skills" no proper training workshops on developing basic skills "limited internship opportunities ' 'little teaching learning activities of practical nature "lack of opportunity to increase analytical skills'

\section{Discussion}

As the rest of the world focuses on improving the quality of teaching and learning, similarly Pakistan is also interested in improving the quality of teaching and learning. The National Qualifications Framework (NQF) was developed by the Higher Education Commission (HEC) in 2002. The National Qualifications Framework focuses on assessing learners' required qualifications and preparing them for national and international qualifications standards. Abbas (2008) highlighted that learning levels in Pakistan were extremely low. Andrabi et al., (2007) also said that student learning levels in Punjab were not according to the international standards.

In comparison to curricular standards and international norms, student learning levels in rural Punjab were low. The purpose of this study was to increase learning outcomes level at $6^{\text {th }}$ of the NQF, which is referred as graduate level. The data collection of this study was divided into two phases: The first phase was quantitative, while the second phase was qualitative. For phase-1 data were collected by using a questionnaire that was converted into Google forms. Planned sample of the Phase-1 was 720 graduates but 1027 questionnaires were received electronically. Findings of the study were: graduate degree gave high level skills to related learning 
outcomes to the graduates. The high level of achieved learning outcomes graduates might be due to self-assessment. Self-assessment rating scales are infamous for their disadvantages like informant generally over-rate their achievements (Karnilowicz, 2012). However, some of the studies have been reported upon the low level of satisfaction in certain educational programmes. For example, McGuinness\& Ortiz, (2016) explained inadequate knowledge, skills, and competence levels among graduates to meet the demands of the workplace.

Gaps in knowledge, skills, and competence have the potential to harm an organization's productivity (McGuinness\& Ortiz, 2016). Manning et al., (2011) also agreed that assessing student learning is beneficial to student improved performance, retention, development, and academic performance.

On the same way, Alshare and Sewailem (2018) conducted a study to reveal a gap analysis of business students' skills in the twenty-first century. The findings revealed that there is a mismatch between perceived business students' skills/competences and required skills/competences. According to Kelly (2015), skills gap is a persistent global issue.

According to Xiang et al., (2013) MBA programmes emphasise the development of knowledge and skills. The aim of this study was to determine the curriculum was aligned with the needs of the employees. This study also became effective in the evaluation of the MBA program's skills and knowledge. This study relied on the use of a questionnaire. Data was collected from 172 MBA graduates. Ninety four percent $(94 \%)$ of MBA graduates agreed that their MBA programme provided them with knowledge and skills.

Alshare and Sewailem (2018) also conducted a study to find out the gap of business students' skills in the 21st Century. Findings of the study were that gap exist between perceived business students' skills and the needed skills. Abbasi and Bibi (2018) also conducted a study for the analysis of skill gap of business graduates. Results showed that employability skills of the graduates were lesser than their expected level.

They stated high level of achieved learning outcomes of university graduates was authenticated by finding the relationship between their actual achievement (earned CGPA) and their perceived level of achieved learning outcomes. It was found that there is no significant relationship between the CGPA of university graduates and their achieved level of learning outcomes. The studies claim weak to moderate relationship between graduates' perceived and actual achievement. In this regard Kamphorst et al., (2013) reported a contrasting picture of the situation, researchers conducted a study among the graduates of Dutch university and to find out relationship between perceived competence and earned credits. Results of the study presented that there exists a week relationship between graduates' perceived competence and their earned credits. 
This contrast in the findings might be supported by certain motives. Firstly, this might be due to contextual difference because European countries have adopted Bologna process decades ago and formulated and implemented their national qualifications frameworks (NQF) in the beginning of $21^{\text {st }}$ century while Pakistan has introduced its national qualifications framework in 2015. Secondly, this might be due the usual biasness in the Pakistani institutions as said by Pervaiz (2020) who conducted a study to analyse the semester examination system in public sector universities of Pakistan. Thirdly, the non-appearance of any relationship between their perceived and actual achievement indicates the fact that the university graduates have rated themselves haphazardly.

\section{Conclusion}

Graduates perceived that they have had high level of skills related achieved learning outcomes of graduate program yet this achievement was lesser than that of the expected level. On the other hand faculty members stated that graduates had achieved medium level of skills related achieved learning outcomes. Furthermore, no relationship was found between graduates' perceived level of skills and their actual achievement (CGPA). Hence, it was concluded that graduates' did not achieve high level of skills related learning outcomes of graduate programme.

Similarly numerous suggestions were given for achievement of high level of skills related to learning outcomes for example it is prerequisite to provide appropriate and well-established lab equipment to develop relevant skills in students; the government must provide funds to bring expensive chemicals and concentrate on research-based education ; particularly in the sciences ; university curricula should be revised according to the market demand; assign a small research project to students in order to improve their research skills; the proportion of practical work should be increased in the curriculum so that students may enhance their skills through involvement in practical work ; needs to develop and promote basic writing skills at earlier stage i.e., at elementary level ; training workshops should be organized to improve basic skills; the scope of internship programme should be extended to all the graduates to provide them an opportunity for enhancing and strengthening their skills ; teachers should ensure involvement of their students in practical work so that they may practice and enhance their skills: learning by doing, 'students should be provided frequent opportunities of planning and conducting small scale projects.

\section{Recommendations}

Based on the current finding of the study, the following recommendations have been made. The achievement gap in learning outcomes demonstrates that university graduates lack of inadequatepractices of basic skills of graduate program learning outcomes. The national qualifications framework specifies these learning outcomes (NQF). As a result, the Pakistani Higher Education Commission should include important sections for the practice of skills in the course outlines for 
graduate programmes. Through their respective departments, HEC may also held mandatory skills orientation seminars for graduate students. University teaching faculty needs to be arranged Special training session's which make them cognisant of learning outcomes for diverse programmes offered by the NQF. 


\section{References}

Abbas, Q., \& Foreman-Peck, J. S. (2008). Human capital and economic growth: Pakistan 1960-2003. Lahore Journal of Economics, 13(1), 1-27. https://doi.org/10.35536/lje.2008.v13.i1.a1

Abbasi, F. K., Ali, A., \&Bibi, N. (2018). Analysis of skill gap for business graduates: managerial perspective from banking industry. Education+ Training.

Adam, S. (2004). Using learning outcomes. In Report for United Kingdom Bologna Seminar (pp. 1-2).

Alshare, K., \&Sewailem, M. F. (2018). A Gap Analysis of Business Students' Skills in the 21st Century: A Case Study of Qatar. Academy of Educational Leadership Journal, 22(1), 1-22. Aryanti, C., \&Adhariani, D. (2020). Students' perceptions and expectation gap on the skills and knowledge of accounting graduates. The Journal of Asian Finance, Economics, and Business, 7(9), 649-657.

Andrabi, T., Das, J., Khwaja, A. I., Vishwanath, T., \&Zajonc, T. (2007). Learning and Educational Achievements in Punjab Schools (LEAPS): Insights to inform the education policy debate. World Bank, Washington, DC.

Creswell, J. W. (2014). A concise introduction to mixed methods research. SAGE publications.

Creswell, J. W., Klassen, A. C., Plano Clark, V. L., \& Smith, K. C. (2011). Best practices for mixed methods research in the health sciences. Bethesda (Maryland): National Institutes of Health, 2013, 541-545.

Greene, J. C. (2007). Mixed methods in social inquiry (Vol. 9). John Wiley \& Sons.

Gupta, P., Saunders, P., \& Smith, J. (2007). Traditional master of business administration (mba) versus the mba with specialization: a disconnection between what business schools offer and what employers seek. Journal of Education for Business, 82 (6), 307-312.

Hobson, C.J., Strupeck, D., Griffin, A., Szostek, J. \&Rominger, A.S. (2014). Teaching MBA students teamwork and team leadership skills: An empirical evaluation of a classroom educational program. American Journal of Business Education, 7(3), 191.

Huma, Z., Baseer, N., \&Mahboob, U. (2020). Cross Matching Learning Outcomes of Postgraduate Basic Medical Sciences to the Qualification Framework of Pakistan. Advances in Basic Medical Sciences, 4(1). 
Karnilowicz, W. (2012). A comparison of self- assessment and tutor assessment of undergraduate psychology students. Social Behaviour and Personality, 40(4), 591- 604. https://doi.org/10.2224/sbp.2012.40.4.591.

Kennedy, D., \& McCarthy, M. (2016). Learning Outcomes in the ECTS Users' Guide 2015. J. Eur. High. Educ. Area, 3.

Kettunen, J., Kairisto-Mertanen, L., \&Penttilä, T. (2013). Innovation pedagogy and desired learning outcomes in higher education. On the horizon.

Lawless, K. A., Schrader, P. G., \&Mayall, H. J. (2007). Acquisition of information online: Knowledge, navigation and learning outcomes. Journal of Literacy Research, 39(3), 289-306.

McGuinness, S. \& Ortiz, L. (2016). Skill gaps in the workplace: Measurement, determinants and impacts. Industrial Relations Journal, 47(3), 253-278.

Oczkowska, R., Wiśniewska, S., \& Lula, P. (2017). ANALYSIS OF THE COMPETENCE GAP AMONG VOCATIONAL SCHOOL GRADUATES IN THE AREA OF SMART SPECIALIZATION IN POLAND. International Journal for Quality Research, 11(4).

Pervaiz, M., Sarwar, M., \& Shah, A. A. (2020). Causes of and Solutions to the Challenges in fair Assessment in Semester System at Public Universities of the Punjab, Pakistan. International Journal of Distance Education and E-Learning, 5(2), 108-122.

Shah, A. A., Syeda, Z. F., \&Shahzadi, U. (2020). Assessment of Higher Education Learning Outcomes of University Graduates. Global Educational Studies Review, 1, 72-83.

Teddlie, C., ETashakkori, A. (2011). Mixed methods research. The Sage handbook of qualitative research, 4, 285-300.

Xiang, C., Lu, Y., \& Gupta, S. (2013). Knowledge sharing in information system development teams: examining the impact of shared mental model from a social capital theory perspective. BehaviourE Information Technology, 32(10), 1024-1040. 